\title{
プライマリ・ケア薬剤師と薬学
}

吉山友二

\section{Primary Care Pharmacist and Pharmacy}

\author{
Yuji YoshiYama \\ Division of Community Pharmacy, Center for Clinical Pharmacy and Clinical Sciences, Kitasato \\ University School of Pharmacy, 5-9-1 Shirokane, Minato-ku, Tokyo 108-8641, Japan
}

医薬分業の展開や医薬品販売の規制緩和がクロー ズアップされて薬学実務教育が拡大する中で, 医療 系の人材としてのセンスと質を具えた薬剤師の役割 が大いに期待されている。地域医療を支える薬剤師 の役割や機能を考え，薬剤師の資質の向上とわが国 のプライマリ・ケアの発展に寄与したい。薬剤師は プライマリ・ケアの理念を持って全人的かつ多角的 に物事を捉えることが必要とされるが，これには専 門的な高いレベルでの知識, 経験, スキルが必須で あり，かつ全般的な能力を備えなければならない。

本誌上シンポジウム「プライマリ・ケア薬剤師と 薬学」の焦点は，プライマリ・ケア薬剤師を実践す るための薬学関連知識を情報提供することである.

ファーマシューティカル・ケアの実践の一部とし て, 薬剂師に応用されるきっかけにして頂ければ幸 いである. 各総説の概要を以下に示す.

(1) 基調講演の「地域医療ネットワークと薬剤師」 では, 武藤正樹氏 (国際医療福祉大学大学院)より, 新たな医療計画の中で, 地域の薬局や薬剤師の役割 もはつきりと明記され，時代の中で薬局・薬剤師は 新たな第一歩を踏夕出すことになったことの重要性 が示唆された。 とりわけ，医療連携ネットワークを 結ぶ情報共有ツールである地域連携クリティカルパ スに果たす薬局の役割について，内視鏡的胃ろう術 （PEG）に関する東京都の港区連携 PEG パス研究 会の事例が魅力的に紹介されている.さらに，これ までのように処方医の処方を右から左に調剤してい ればよい時代は終わった。そして地域における薬

北里大学薬学部臨床薬学研究・教育センター臨床薬学 （保険薬局学）（T108-8641 東京都港区白金 5-9-1） e-mail: yoshiyamay@pharm.kitasato-u.ac.jp 日本薬学会第 130 年会シンポジウム S07 序文
局・薬剤師の役割や真価が問われる時代の到来であ るとの強いエールを頂戴した.

(2)「薬学のスキルを活用した OTC 医薬品の提 供」では, 堀内 正氏（岐阜薬科大学）より，一般 用医薬品（OTC 医薬品）に関する教育や OTC 医 薬品の販売を取り巻く現状なども含めて, 薬剤師に よる OTC 医薬品の提供の現状と将来について言及 されている。利用者の意識調査から，適正なセルフ メディケーションが行われるためには, OTC 医薬 品の利用者への十分な情報提供と適切なセルフメデ イケーションについての啓発の必要性を示されてい る．また，処方薬に対する服薬説明を行っている薬 学のスキルをもって OTC 医薬品及び情報提供を行 えば，適切なセルフメディケーションの推進に寄与 できることを提案されている。これからの薬剤師, 特に保険薬局の薬剤師は, OTC 医薬品によるセル フメディケーションなどを通じて, General practitioner の役割の一部を担うように努める必要があ ると結論された.

(3)「プライマリケアで役立てるコーチング」で は, 野呂瀬崇彦氏（北海道薬科大学）より, 薬剤師 がプライマリ・ケアに取り組む上で，患者さんとど のように係わっていくべきか, 特に近年注目されて いる対人支援手法の 1 つであるコーチングがどのよ うに活用できるか概説されている，プライマリ・ケ アが主として担うのは予防・初期医療と療養継続医 療の部分であることから, 患者の生活習慣改善意識 や, 症状, 副作用の早期発見のための知識などが効 果的で安全な医療を実現する上では患者がセルフコ ントロールできる部分, すなわち患者自身が自分の 医療に積極的に介入できる部分が大きい。予防・初 期医療においてセルフメディケーションは重要な概 
念であり, 薬剂師としてその職能を発揮すべき領域 においては，コーチングという係わり方は，患者中 心の医療を進める上では有効な介入方法であること が期待される.

(4)「プライマリ・ケアの地域住民啓発事業」で は，オーガナイザーの飯塚敏美氏(望星薬局)より， プライマリ・ケアの地域住民啓発事業の具体的事例 として，C 型慢性肝炎治療における医療機関と保険 薬局の連携が紹介されている，基調講演で武藤氏も 強調されているように，最近では，地域医療連携と 保険薬局の役割がクローズアップされている．薬局 薬剤師が地域医療連携に積極的に係わることは，患 者背景の把握や患者にとつて安全な薬物療法を実践 するきっかけとなり，プライマリ・ケア薬剤師の職 能発揮の好機であると思われる。お薬手帳を活用し た病診薬薬連携として, お薬手帳型 C 型慢性肝炎 治療地域連携パスの特徵が概説され，プライマリ・ ケア薬剤師を実践する上で，優れたツールであるこ とが示されている.

シンポジストであるが誌上シンポジウムに参加し なかった，「プライマリ・ケア薬剤師に期待する」 と「プライマリ・ケアと薬学」の概要を記す。内山 充氏(薬剂師認定制度認証機構)より, プライマリ・ ケア領域での職能を身につけた薬剤師には，市民生 活における健康上の不安解消のための信頼の置ける 相談相手として，様々な活動が期待されることが示 された。薬剤師の社会的責務として最も期待されて いる分野であり，地域社会の健全な発展に貢献する ために，できるだけ多くの薬剤師が，このことを認 識し，役割を果たすための努力をする必要があるこ
とが提言された。そのためには，薬学本来の基盤的 知識を生かしながら，目的をしつかりと見据えた計 画的な学習による，生涯を通じた継続的な職能向上 の努力が必要であると結論した。また，吉山友二 (北里大学薬学部) は，プライマリ・ケアについて は，病院外来薬剤業務では対応に限界があるため, 当然のことながら保険薬局の役割が求められること から，プライマリ・ケアにおけるファーマシューテ イカル・ケア実践のチャンスが今，訪れていること を強調した．新しい形の実践に身をゆだね，すぐに 具体的行動を開始すれば薬剤師によるファーマシ ユーティカル・ケアがプライマリ・ケアを中心とし て実践される意義は大であると結論した。

本誌上シンポジウムは, 2010 年 3 月に開催され た日本薬学会第 130 年会でのシンポジウム「プライ マリ・ケア薬剂師と薬学」での発表を元に, シンポ ジストの先生方に最新の知見をまとめて頂いた.

ファーマシューティカル・ケアの実践は薬剤師の 集大成とも言え，より多くの薬剤師によるプライマ リ・ケアを意識した取り組みが必要であり，ファー マシューティカル・ケアの実践に関する誌上シンポ ジウムをまとめることは, 相互の会員にとって大変 有意義なことと思われる，臨床はもちろんのこと， 基礎とよき相互連携しつつ, ファーマシューティカ ル・ケアを展開したいものである，これらの誌上シ ンポジウムの内容を通読することにより，プライマ リ・ケアを含めたファーマシューティカル・ケアの 実践に応用することが薬学関係者の腕の見せ所と確 信している. 